\title{
Borrelia burgdorferi IgG and IgM Antibody Measurement
}

National Cancer Institute

\section{Source}

National Cancer Institute. Borrelia burgdorferi Ig G and IgM Antibody Measurement. NCI

Thesaurus. Code C147310.

The determination of the amount of Borrelia burgdorferi IgG and IgM antibody present in a sample. 